University of Wollongong

Research Online

Faculty of Science - Papers (Archive)

Faculty of Science, Medicine and Health

January 2007

\title{
Nutrigenomics applied to an animal model of Inflammatory Bowel \\ Diseases: Transcriptomic analysis of the effects of eicosapentaenoic acid- and arachidonic acid-enriched diets
}

\author{
Nicole Roy \\ Massay University \\ Matthew Barnett \\ Nutrigenomics New Zealand \\ Bianca Knoch \\ University of Wollongong, knochb@gmail.com \\ Yvonne Dommels \\ Nutrigenomics New Zealand \\ Warren McNabb \\ Nutrigenomics
}

Follow this and additional works at: https://ro.uow.edu.au/scipapers

Part of the Life Sciences Commons, Physical Sciences and Mathematics Commons, and the Social and Behavioral Sciences Commons

\section{Recommended Citation}

Roy, Nicole; Barnett, Matthew; Knoch, Bianca; Dommels, Yvonne; and McNabb, Warren: Nutrigenomics applied to an animal model of Inflammatory Bowel Diseases: Transcriptomic analysis of the effects of eicosapentaenoic acid-and arachidonic acid-enriched diets 2007, 103-116.

https://ro.uow.edu.au/scipapers/765

Research Online is the open access institutional repository for the University of Wollongong. For further information contact the UOW Library: research-pubs@uow.edu.au 


\title{
Nutrigenomics applied to an animal model of Inflammatory Bowel Diseases: Transcriptomic analysis of the effects of eicosapentaenoic acid-and arachidonic acid-enriched diets
}

\begin{abstract}
In vivo models of Inflammatory Bowel Diseases (IBD) elucidate important mechanisms of chronic inflammation. Complex intestinal responses to food components create a unique "fingerprint" discriminating health from disease. Five-week-old IL10-/- and C57BL/6J (C57; control) mice were inoculated orally with complex intestinal microflora (CIF) and/or pure cultures of Enterococcus faecalis and $\mathrm{E}$. faecalis (EF) aiming for more consistent inflammation of the intestinal mucosa. Inoculation treatments were compared to non-inoculated IL10-/- and C57 mice, either kept in specific pathogen free (SPF) or conventional conditions ( $2 \times 5$ factorial design). At 12 weeks of age, mice were sacrificed for intestinal histological (HIS) and transcriptomic analysis using limma and Ingenuity Pathway Analysis Software. Colonic HIS was significantly affected $(P<0.05)$ in inoculated IL10-/- mice and accounted for approximately $60 \%$ of total intestinal HIS. Inoculation showed a strong effect on colonic gene expression, with more than 2000 genes differentially expressed in EF.CIF-inoculated IL10-/- mice. Immune response gene expression was altered $(P<0.05)$ in these mice. The second study investigated the effect of arachidonic (AA) and eicosapentaenoic acid (EPA) on colonic HIS and gene expression to test whether EPA, contrary to AA, diminished intestinal inflammation in EF.CIF IL10-/- mice ( $2 \times 4$ factorial design). AIN-76A (5\% corn oil) and AIN-76A (fat-free) +1\% corn oil supplemented with either $3.7 \%$ oleic acid (OA), AA or EPA were used. IL10-/- mice fed EPA- and AA-enriched diets had at least $40 \%$ lower colonic HIS (P $<0.05$ ) than those fed control diets (AIN-76A and OA diets). The expression of immune response and 'inflammatory disease' genes (down-regulated: TNF, IL6, S100A8, FGF7, PTGS2; up-regulated: PPAR, MGLL, MYLK, PPSS23, ABCB4 with EPA and/or AA) was affected in IL10-/-mice fed EPA- and AAenriched diets, compared to those fed AIN-76A diet.
\end{abstract}

\section{Keywords}

nutrigenomics, analysis, effects, eicosapentaenoic, inflammatory, model, acid, animal, arachidonic, enriched, diets, applied, bowel, diseases, transcriptomic

\section{Disciplines}

Life Sciences | Physical Sciences and Mathematics | Social and Behavioral Sciences

\section{Publication Details}

Roy, N., Barnett, M., Knoch, B., Dommels, Y. \& McNabb, W. (2007). Nutrigenomics applied to an animal model of Inflammatory Bowel Diseases: Transcriptomic analysis of the effects of eicosapentaenoic acidand arachidonic acid-enriched diets. Mutation Research, 622 103-116. 


\title{
Nutrigenomics applied to an animal model of Inflammatory Bowel Diseases: Transcriptomic analysis of the effects of eicosapentaenoic acid- and arachidonic acid-enriched diets
}

\author{
Nicole Roy ${ }^{\mathrm{a}, \mathrm{d}}$, Matthew Barnett ${ }^{\mathrm{a}, \mathrm{d}}$, Bianca Knoch ${ }^{\mathrm{a}, \mathrm{b}, \mathrm{d}}$, \\ Yvonne Dommels ${ }^{\mathrm{c}, \mathrm{d}, 1}$, Warren McNabb ${ }^{\mathrm{a}, \mathrm{d}, *}$ \\ ${ }^{a}$ Food, Metabolism \& Microbiology Section, Food \& Health Group, AgResearch Grasslands, Palmerston North, New Zealand \\ ${ }^{\mathrm{b}}$ Institute of Food, Nutrition \& Human Health, Massey University, Palmerston North, New Zealand \\ ${ }^{\mathrm{c}}$ Nutrition \& Health Team, Crop \& Food Research, Palmerston North, New Zealand \\ ${ }^{\mathrm{d}}$ Nutrigenomics New Zealand, New Zealand ${ }^{2}$
}

Received 24 January 2007; received in revised form 30 March 2007; accepted 12 April 2007

Available online 19 April 2007

\begin{abstract}
In vivo models of Inflammatory Bowel Diseases (IBD) elucidate important mechanisms of chronic inflammation. Complex intestinal responses to food components create a unique "fingerprint" discriminating health from disease. Five-week-old IL $10^{-/-}$and C57BL/6J (C57; control) mice were inoculated orally with complex intestinal microflora (CIF) and/or pure cultures of Enterococcus faecalis and E. faecalis (EF) aiming for more consistent inflammation of the intestinal mucosa. Inoculation treatments were compared to non-inoculated IL10 ${ }^{-l-}$ and C57 mice, either kept in specific pathogen free (SPF) or conventional conditions $(2 \times 5$ factorial design). At 12 weeks of age, mice were sacrificed for intestinal histological (HIS) and transcriptomic analysis using limma and Ingenuity Pathway Analysis Software. Colonic HIS was significantly affected $(P<0.05)$ in inoculated IL10 $0^{-/-}$mice and accounted for approximately $60 \%$ of total intestinal HIS. Inoculation showed a strong effect on colonic gene expression, with more than 2000 genes differentially expressed in EF.CIF-inoculated $\mathrm{IL} 10^{-1-}$ mice. Immune response gene expression was altered $(P<0.05)$ in these mice. The second study investigated the effect of arachidonic (AA) and eicosapentaenoic acid (EPA) on colonic HIS and gene expression to test whether EPA, contrary to AA, diminished intestinal inflammation in EF.CIF IL10 ${ }^{-/-}$mice $(2 \times 4$ factorial design). AIN-76A (5\% corn oil) and AIN-76A (fat-free) $+1 \%$ corn oil supplemented with either $3.7 \%$ oleic acid (OA), AA or EPA were used. IL10 $0^{-1-}$ mice fed EPA- and AA-enriched diets had at least $40 \%$ lower colonic HIS $(P<0.05)$ than those fed control diets (AIN-76A and OA diets). The expression of immune response and 'inflammatory disease' genes (down-regulated: TNF $\alpha$, IL6, S100A8, FGF7, PTGS2; up-regulated: PPAR $\alpha$, MGLL, MYLK, PPSS23, ABCB4 with EPA and/or AA) was affected in IL10 ${ }^{-/-}$ mice fed EPA- and AA-enriched diets, compared to those fed AIN-76A diet.
\end{abstract}

(C) 2007 Elsevier B.V. All rights reserved.

Keywords: Inflammatory Bowel Diseases; IL10 $10^{-/-}$mice; Colon; Gene expression; Dietary polyunsaturated fatty acids

\footnotetext{
* Corresponding author at: Food, Metabolism \& Microbiology Section, Food \& Health Group, AgResearch Grasslands, Palmerston North, New Zealand. Tel.: +64 6351 8061; fax: +64 63518003.

E-mail address: warren.mcnabb@agresearch.co.nz (W. McNabb).

${ }_{1}$ Present address: Unilever Food \& Health Research Institute, Vlaardingen, The Netherlands.

2 www.nutrigenomics.org.nz.
} 


\section{Introduction}

The intestinal tract is the largest interface where human beings interact with their environment. This complex system consists of different cell types, harbors up to $10^{13}$ bacteria - more than 10 times the number of cells in the body [1] - and comprises 70\% of the body's immune system [2]. Four protective barriers maintain the integrity of this interface: the epithelial barrier [3], the chemical barrier [4], the microbiological barrier [1] and the immunological barrier [5,6]. The disruption of one or more of these barriers can lead to chronic inflammation which is a hallmark of intestinal disorders such as Ulcerative Colitis [7] and Crohn's Disease [8,9], collectively referred to as Inflammatory Bowel Diseases (IBD). Current in vitro models, while useful for screening components, are unable to mimic the level of complexity of the intestinal system. Thus, in vivo models of IBD are important for unraveling the complex interactions between food, intestinal bacteria and intestinal cells, thereby elucidating the mechanisms by which IBD are initiated and maintained.

While the exact etiology and pathogenesis of IBD is still unclear, there is strong epidemiological evidence for a genetic contribution to disease susceptibility. Since IL10 ${ }^{-/-}$mice spontaneously develop intestinal enterocolitis, they have been used extensively as a model of IBD [10-12]. IL10 is an anti-inflammatory cytokine which affects the growth and differentiation of various cell types of the immune system in vitro [13] and suppresses their function by inhibiting production of numerous cytokines by these cells [14]. Thus, IL10 is an important regulator of intestinal mucosal responses [15]. The severity of enterocolitis in $\mathrm{IL} 10^{-/-}$mice is dependent on the breeding background, with BALB/c mice showing the most severe symptoms and C57BL/6 J the least severe [16]. In the case of the latter, IL10 ${ }^{-/-}$ mice develop CD-like colitis by 12 weeks of age but this is not the case when they are raised under specific pathogen free (SPF) conditions [16]. Other studies report that under SPF conditions, IL10 ${ }^{-/-}$mice do develop colitis, but it is less severe and is not observed before 20 weeks of age [17]. The mechanistic defect causing inflammation in IL10 ${ }^{-/-}$mice is unclear but intestinal bacteria are necessary for the initiation and progression of inflammation [18].

Results from our laboratory using $\mathrm{IL}_{10}{ }^{-/-}$mice (C57BL/6J background) showed individual variability between animals with respect to the occurrence and severity of intestinal inflammation [19]. In the first part of this paper, we describe an experiment in which the effect of inoculation with intestinal bacteria was tested in IL10 $10^{-1-}$ mice to determine whether this would result in a more consistent and reproducible mucosal inflammation in the intestine. Histological injury score and gene expression in intestinal tissues of IL $10^{-/-}$mice inoculated with populations of bacteria commonly found in the intestinal lumen, either complex intestinal microflora (CIF) and/or pure cultures of intestinal bacteria such as Enterococcus faecalis and E. faecium (EF) [20], were measured. These bacteria were introduced into the intestinal tract at a similar level to wild-type animals in normal conditions, with the aim of ensuring that bacterial colonization and subsequent exposure to potential inflammatory factors occurred at a similar level across all treatments.

In the second part of this paper, preliminary findings on the effect of two polyunsaturated fatty acids (PUFA), arachidonic (AA) and eicosapentaenoic acid (EPA), on intestinal inflammation are presented. AA is a precursor for the synthesis of eicosanoids, which are modulators of defensive and inflammatory processes in the intestinal mucosa [21]. EPA can inhibit AA metabolism competitively via the cyclo-oxygenase enzymatic pathways and thereby suppress the production of AA inflammatory mediators [21]. We hypothesize that contrary to AA, EPA diminishes both the severity of the lesions and the progression of induced intestinal inflammation. The aim was to identify these interactions using bacterially inoculated IL10 ${ }^{-/-}$mice, with principal outcomes being histological injury score and differential gene expression using transcriptomic analysis.

\section{Material and methods}

The experimental procedures for these trials were reviewed and approved by the Crown Research Institute Animal Ethics Committee in Hamilton, New Zealand, according to the Animal Protection Act (1960) and Animal Protection Regulations (1987) and amendments.

\subsection{Animals}

Male mice, 4-5 weeks of age were used for all experiments. IL $10^{-1-}$ mice (B6.129P2-IL $10<\operatorname{tm} 1 \mathrm{Cgn}>/ \mathrm{J}$ ) and C57 controls (C57BL/6J) were purchased from the Jackson Laboratory (Bar Harbor, Maine, USA), and individually housed under conventional conditions (12-h light:12-h dark cycle (lights on from 08:00 to 20:00 h), temperature of $22 \pm 1{ }^{\circ} \mathrm{C}$ and approximately $50 \%$ relative humidity) in shoebox-style cages containing untreated wood shavings (Hi Tech Security Disposals Ltd., Auckland, New Zealand) and a plastic tube for environmental enrichment. All mice were given water and, unless otherwise stated, fed a non-sterile, AIN-76A powdered diet made in-house (Table 1). Food intake 
Table 1

Composition of the AIN-76A diet and the AIN-76A diets enriched with oleic acid (OA), arachidonic acid (AA) and eicosapentaenoic acid (EPA)

\begin{tabular}{|c|c|c|c|c|}
\hline \multirow[t]{2}{*}{ Dietary ingredient } & \multicolumn{4}{|c|}{ Percentage in the diet } \\
\hline & AIN-76A & OA & EPA & AA \\
\hline Casein $^{a}$ & 20 & 20 & 20 & 20 \\
\hline DL-methionine ${ }^{\mathrm{b}}$ & 0.3 & 0.3 & 0.3 & 0.3 \\
\hline Sucrose $^{c}$ & 50 & 50 & 50 & 50 \\
\hline Dextrin $^{\mathrm{d}}$ & 15 & 15 & 15 & 15 \\
\hline Arbocel, non-nutritive bulk ${ }^{\mathrm{e}}$ & 5 & 5 & 5 & 5 \\
\hline Corn oil $^{\mathrm{f}}$ & 5 & 1 & 1 & 1 \\
\hline $\mathrm{C} 18: 2,99 \%++^{\mathrm{g}}$ & 0 & 0.20 & 0.20 & 0.20 \\
\hline $\mathrm{C} 18: 3,99 \%+{ }^{\mathrm{h}}$ & 0 & 0.06 & 0.06 & 0.06 \\
\hline Oleic acid, $99 \%+$ & 0 & 3.74 & 0 & 0 \\
\hline Eicosapentaenoic acid, $98 \%+$ & 0 & 0 & 3.74 & 0 \\
\hline Arachidonic acid, $99 \%+$ & 0 & 0 & 0 & 3.74 \\
\hline Choline bitartrate $\mathrm{e}^{\mathrm{b}}$ & 0.2 & 0.2 & 0.2 & 0.2 \\
\hline AIN-76A Mineral Mix ${ }^{\mathrm{i}}$ & 3.5 & 3.5 & 3.5 & 3.5 \\
\hline AIN-76A Vitamin Mix ${ }^{i}$ & 1 & 1 & 1 & 1 \\
\hline Ethoxyquin $^{\mathrm{b}}$ & 0.01 & 0 & 0 & 0 \\
\hline $\mathrm{TBHQ}^{\mathrm{j}}$ & 0 & 0.001 & 0.001 & 0.001 \\
\hline
\end{tabular}

All diets were prepared in-house using ingredients from the suppliers listed, and according to the compositions shown.

a Alacid, lactic casein 30 mesh, NZMP Ltd., Wellington, New Zealand.

b Sigma, Sigma-Aldrich Inc., St. Louis, MO, USA.

c Caster sugar, Chelsea, New Zealand Sugar Company Limited, Auckland, New Zealand.

d Wheaten cornstarch, Golden Harves, Primary Foods Ltd., Auckland, New Zealand.

e Arbocell B600, J. Rettenmaier \& Sohne GmbH+ Co, Rosenberg, Germany.

f Tradewinds, Davis Trading, Palmerston North, New Zealand.

g C18:2, linoleic acid.

${ }^{\text {h }}$ C18:3, alpha-linolenic acid.

${ }^{\mathrm{i}}$ Prepared in-house based on the AIN-76A diet formulation [46].

$\mathrm{j}$ TBHQ, Tertiary butylhydroquinone as antioxidant.

was measured daily and water was refreshed twice a week. The food intake of all mice was adjusted daily to equal the mean amount of food consumed by the $\mathrm{IL} 10^{-/-}$mice on the previous day. Growth performance was measured a minimum of thrice weekly. All mice were carefully monitored for disease symptoms (weight loss, soft faeces, inactivity). Tissue sampling and downstream analyses were performed as described below.

\subsection{Inoculation study in $I L-10^{-/-}$mice}

Twenty-five male C57 mice and 25 male IL10 ${ }^{-1-}$ mice (C57BL/6J background) were used (Fig. 1). Upon arrival (4 weeks of age), five C57 and five IL10 ${ }^{-/-}$mice were housed in SPF conditions (isolator cages). All mice were fed AIN$76 \mathrm{~A}$ powdered diet (Table 1) sterilized by gamma radiation suitable for SPF (Schering-Plough, Wellington, New Zealand). The other $20 \mathrm{C} 57$ and 20 IL10 $0^{-1-}$ mice were housed in conventional conditions. At 5 weeks of age, 15 of each strain were inoculated orally with the three different preparations of bacteria commonly found in the intestinal lumen $\left(5 \mathrm{IL} 10^{-/-}\right.$mice and 5 C57 mice each for each different bacterial preparation).

Five C57 mice and five IL10 ${ }^{-/-}$mice housed in conventional conditions were inoculated with a culture of $E$. faecalis and E. faecium (EF; 12 calf and chicken strains obtained from AgResearch Microbiology Group in Palmerston North; $1.2 \times 10^{8}$ colony forming units). The Enterococcus strains were subcultured onto fresh Slanetz \& Bartley medium (Oxoid, Hampshire, UK) and incubated at $42{ }^{\circ} \mathrm{C}$ for $48 \mathrm{~h}$, then transferred to Todd-Hewitt Broth (Oxoid, Hampshire, UK) and incubated at $37^{\circ} \mathrm{C}$ for $24 \mathrm{~h}$. All strains were then centrifuged $\left(2000 \times g, 10 \mathrm{~min}, 4^{\circ} \mathrm{C}\right)$, re-suspended in sterile $1 \times \mathrm{PBS}$, and pooled for inoculation.

Another five C57 and five IL10 ${ }^{-/-}$mice were inoculated with complex intestinal flora (CIF; $200 \mu \mathrm{L})$. The CIF solution was prepared by harvesting digesta from age-matched C57BL/6 mice raised under conventional conditions following humane euthanasia by $\mathrm{CO}_{2}$ asphyxiation and cervical dislocation. Briefly, the intestinal tract (from pyloric sphincter to caecum) was removed and digesta were collected from the intestine and caecum and suspended in sterile $1 \times$ PBS.

The final group of five C57 and five $\mathrm{IL}_{10}{ }^{-1-}$ mice was inoculated with $200 \mu \mathrm{L}$ of an inoculation solution consisting of a $1: 1(\mathrm{v} / \mathrm{v})$ mixture of the EF $\left(6.0 \times 10^{7} \mathrm{CFU}\right)$ and CIF solutions described above (EF.CIF).

The EF, CIF and EF.CIF treatments were compared with each other and to non-inoculated $\mathrm{C} 57$ and $\mathrm{IL}_{10}^{-1-}$ mice and C57 and IL10 ${ }^{-1-}$ mice kept in SPF according to a $2 \times 5$ factorial design. At 12 weeks of age, all mice were sacrificed and sampling performed to harvest tissues and body fluids for histology evaluation and transcriptomic analysis of intestinal tissues as described below.

\subsection{PUFA experiment with $I L 10^{-/-}$mice}

Twenty-four male C57 mice and 24 male $\mathrm{IL}_{10}^{-1-}$ mice were inoculated according to the EF.CIF protocol described above to obtain consistent and reproducible intestinal inflammation. A powdered diet based on AIN-76A (Table 1) was used to facilitate the mixing of EPA and AA compounds. Mice were randomly assigned to the following diets (Table 1) according to a $2 \times 4$ factorial design: (1) AIN-76A (5\% corn oil), (2) AIN-76A (fat-free) $+1 \%$ corn oil $+3.7 \%$ oleic acid (OA), (3) AIN-76A (fat-free) $+1 \%$ corn oil $+3.7 \%$ AA and (4) AIN-76A (fat-free) $+1 \%$ corn oil $+3.7 \%$ EPA (Fig. 1). The $1 \%$ corn oil was supplemented with purified linoleic acid and alpha-linolenic acid to meet the nutritional requirements of mice for these essential fatty acids [22]; the OA, EPA and AA diets had 5\% fat as in the AIN-76A diet. The ethyl ester of OA was used to make an OA-enriched control diet so that AA and EPA in PUFA-enriched diets could be substituted for OA. OA was chosen as the control fatty acid because it has no effect on tissue contents of AA and EPA and on eicosanoid biosynthesis [23]. Esters of AA, OA, linoleic acid and alpha-linolenic acid (99\% purity, NuCheck Inc., Elysian, MN, USA) and EPA $(98 \%$ purity, Brainfats Biotechnology Limited, Auckland, New 

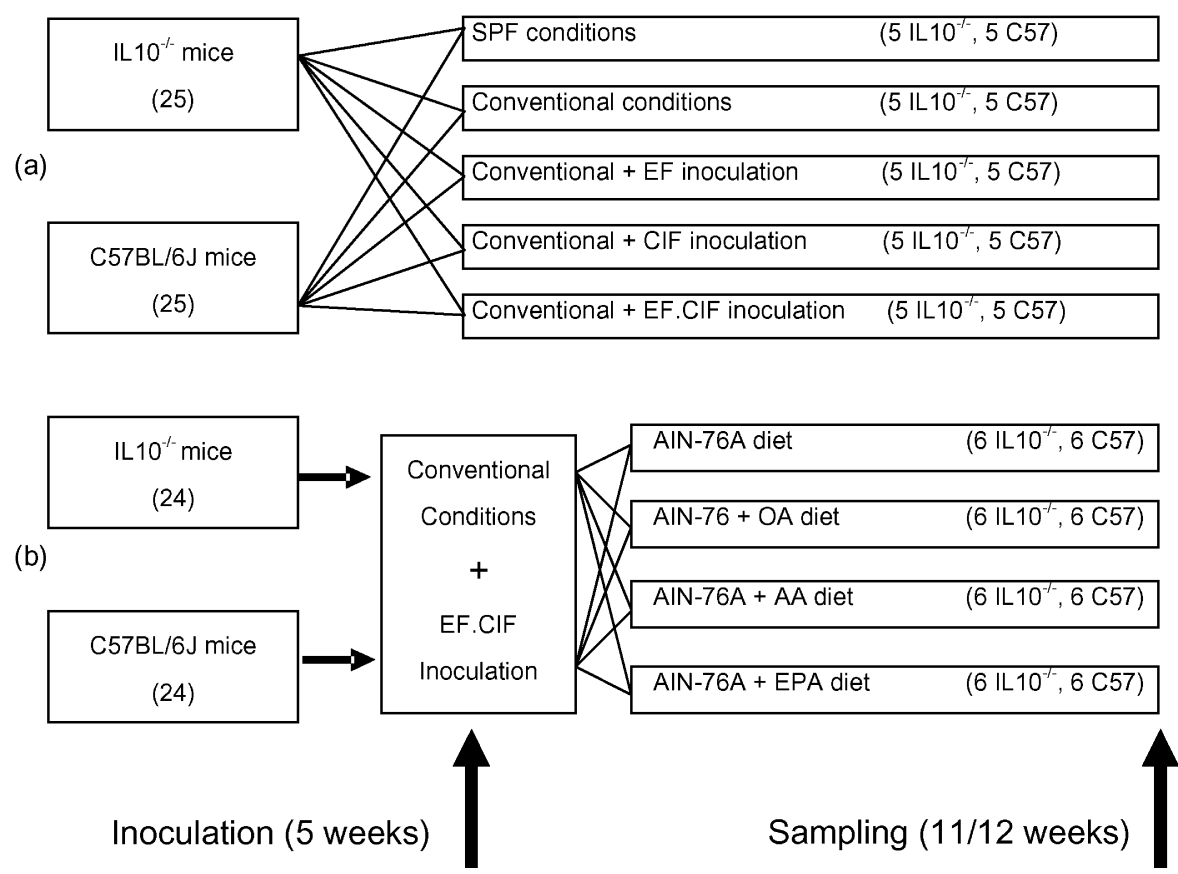

Fig. 1. Overall study design, showing the inoculation (a) and PUFA (b) experiments. For both experiments, mice were fed experimental diets from 4.5 weeks of age. In the case of the inoculation study, the diet was AIN-76A for all groups, while for the PUFA trial the diets are as shown in the figure and described in Table 1. Inoculation was performed at 5 weeks of age; for the inoculation experiment, this was as described in Section 2.2, while for the PUFA experiment all animals were inoculated with a mixture of Enterococcus faecalis and Enterococcus faecium strains and conventional intestinal flora derived from normal C57BL/6 mice raised under conventional conditions (EF.CIF). Tissue sampling was performed at 11 and 12 weeks of age, respectively, for the PUFA and inoculation experiments.

Zealand) were used. Between 5 and 11 weeks of age food consumption and growth performance were recorded as described previously. At 11 weeks of age, all mice were sacrificed and sampling performed to harvest tissue and body fluids for histology evaluation and transcriptomic analysis of intestinal tissues as described below. This tissue sampling time was selected based on a previous study, where $\mathrm{IL} 10^{-1-}$ mice inoculated with EF.CIF at 5 weeks of age showed an acceptable and consistent level of colonic inflammation by 11 weeks of age [24].

\subsection{Tissue sampling}

Before sacrifice, mice were fasted overnight (14h), after which food was re-offered for $2 \mathrm{~h}$. Food was again removed for the $2 \mathrm{~h}$ prior to sampling. This was to minimize the variation in time between the last food intake and tissue sampling [25]. A maximum of 12 mice were euthanized on each day; $14 \mathrm{~h}$ overnight fasting and tissue sampling were staggered in three groups of four mice, with $1 \mathrm{~h}$ between each group. Animals were euthanized via $\mathrm{CO}_{2}$ asphyxiation and cervical dislocation. Blood was sampled via cardiac puncture $(0.5-1 \mathrm{~mL})$, and cells were separated from plasma by centrifugation $(2000 \times g$, $3 \mathrm{~min}$, room temperature). Plasma was removed, immediately frozen in liquid nitrogen and stored at $-85^{\circ} \mathrm{C}$. Pelleted blood cells were re-suspended in RNAlater ${ }^{\circledR}$ (Ambion, Austin, TX, USA) and frozen for subsequent RNA extraction. Spleen, liver, thymus, kidneys and skeletal muscle were quickly removed and frozen in liquid nitrogen. The intestine was quickly removed, cut open lengthwise and flushed with $0.9 \% \mathrm{NaCl}$ to remove any traces of digesta, then carefully laid out on an ice cold stainless steel tray. Sections of duodenum, jejunum, ileum and colon were fixed in $10 \%$ phosphate-buffered formalin and stored at room temperature until histological evaluation of inflammation. Samples of the same tissue were also rapidly frozen in liquid nitrogen before storage at $-85^{\circ} \mathrm{C}$ for gene and protein profiling.

\subsection{Histopathology}

Formalin-fixed intestinal tissue samples were embedded in paraffin and processed for sectioning [26]. Embedded tissue samples were sliced to obtain $5 \mu \mathrm{m}$ thick sections which were stained with haematoxylin and eosin for light microscopic examination. Stained sections were assessed for inflammation based on a combination of inflammatory cell infiltration (monocytes, neutrophils, fibrin exudation and lymphangiectasis), tissue destruction (oedema and mucosal atrophy) and tissue repair (hyperplasia, angiogenesis, granulomas and fibrosis) [26]. A rating score between 0 (no change from normal tissue) and 3 (lesions involved most areas and all the layers of the intestinal section including mucosa, muscle and omental fat) was applied to each intestinal section (ileum, colon, etc.) for each aspect of inflammation (e.g. 
monocytes, oedema, hyperplasia, etc.). The sum of scores for inflammatory cell infiltration (multiplied by 2), tissue destruction and tissue repair was used to represent the total histological injury score (HIS) for each intestinal section. The sum of the inflammatory cell infiltration was multiplied by 2 to give more weight to this value, as this represented the main characteristic of the observed inflammation. Gene expression analysis was performed only if significant changes in histopathology were observed in any intestinal section.

\subsection{Gene expression hybridization}

For microarray hybridization, total RNA from intestinal tissues was isolated by homogenizing the samples in TRIzol (Invitrogen, Auckland, New Zealand), a modification of the acid guanidinium thiocyanate-phenol-chloroform extraction method [27], according to the manufacturer's instructions. RNA was quantified with a Nanodrop ND-1000 spectrophotometer (NanoDrop Technologies, Wilmington, DE, USA), and RNA integrity was assessed with an RNA 6000 Nano LabChip kit using the Agilent 2100 Bioanalyser (Agilent Technologies, Santa Clara, CA, USA). Extracted RNAs were purified using RNeasy spin columns (QIAGEN, San Diego, CA, USA). Only total RNA with an OD 260/280 ratio > 2.0, a Bioanalyzer $28 \mathrm{~s} / 18 \mathrm{~s}$ peak ratio $>1.2$ and a RIN number superior to 8 was used for microarray hybridization. An equimolar pool of two to three total RNA extracts from intestinal tissues of two to three different mice per treatment was made. Reference RNA was used for microarray hybridization. For the inoculation trial, RNA extracts from control and treated mice were pooled in an equimolar proportion and used as the reference sample. For the PUFA trial, equimolar RNA extracts from small intestine, colon, kidney and liver of normal healthy growing Swiss mice plus RNA extracts from Swiss mouse fetuses were pooled to make a universal reference RNA for use in all subsequent trials.

RNA samples (experimental and reference pools) were labeled using the Agilent Low RNA Input Linear Amplification Kit (5184-3523) according to the manufacturer's instructions. Briefly, $500 \mathrm{ng}$ of total RNA was amplified and reverse transcribed in vitro to cDNA using T7-polymerase, which was subsequently labeled with either cyanine3 (experimental) or cyanine5 (reference)-labeled CTP (10 mM; Perkin-Elmer/NEN Life Science (NEL 580, 581), Boston, MA, USA) dye. A Nanodrop ND-1000 spectrophotometer was used to monitor dye incorporation for the experimental samples $(500 \mathrm{ng}$ ) which was between 9 and $22 \mathrm{pmol} / \mu \mathrm{g}$. Targets consisting of amplified and fluorescent-labeled cRNA were hybridized using the Agilent oligonucleotide microarray in situ hybridization plus kit (5184-3568), following the manufacturer's protocols. Briefly $750 \mathrm{ng}$ of pooled treatment cRNA was mixed with $750 \mathrm{ng}$ of pooled reference cRNA in the presence of a control target, fragmented for $30 \mathrm{~min}$ at $60^{\circ} \mathrm{C}$ in the dark and hybridized onto Agilent Technologies 44k (G4122-60510) mouse 60 mer oligonucleotide arrays in a rotation oven $\left(60^{\circ} \mathrm{C}\right.$, $17 \mathrm{~h}, 4 \mathrm{rpm}$ in the dark). Following hybridization, chambers were disassembled and the slides sequentially washed in solutions I, II and III (Agilent Technologies, Santa Clara, CA, USA) and air-dried. Slides were then scanned using a GenePix Professional 4200A scanner (Molecular Devices, Sunnyvale, CA, USA); a photomultiplier tube voltage of 550 (red laser) and 545 (green laser) was applied for the inoculation trial, and a photomultiplier tube voltage of 585 (red laser) and 600 (green laser) for the PUFA trial. Spot identification and quantification was performed with GenePix 6.0 software (Molecular Devices).

\subsection{Statistical analysis}

Statistical analyses of body weight and histological injury score were performed in GenStat (eighth ed., VSN International, Hemel Hempstead, UK, 2005). One-way ANOVA was used to detect significant differences between treatments. Log transformed values were used for the statistical analysis of HIS scores. A probability value less than 0.05 was regarded as significant and probability less than 0.10 but higher than 0.05 was declared a trend.

Intensity ratio values for all microarray spots were normalized using global lowess normalization without background correction (inoculation trial) and with background correction (PUFA trial). Relative amounts of the two dyes were used to determine the level of expression of a particular gene in $\mathrm{IL} 10^{-/-}$ mice compared to C57 mice. For each comparison a candidate list of differentially expressed genes was generated using linear models for microarray analysis (limma) within the Bioconductor framework [28]. For IL10 ${ }^{-1-}$ versus C57 (control diet) comparisons in both the inoculation and PUFA experiments, moderated $t$-statistics and false discovery rate control with probability less than 0.05 - and 1.5 -fold-change as statistical filtering criteria were used. For IL10 ${ }^{-1-}$ versus C57 (PUFA diets) comparisons, moderated $t$-statistics and probability less than 0.05- and 1.3-fold-change as statistical filtering criteria were used due to fewer genes being differently expressed, often with a lower fold-change compared to the inflammation comparison [28]. Differentially expressed genes from the inoculation and PUFA experiments were clustered into pathways using Ingenuity Pathway Analysis (Ingenuity Systems Inc., Redwood City, CA, USA).

This paper presents preliminary microarray results for both the inoculation and PUFA trial. Validation of gene expression changes is on-going; in this paper, only genes with a foldchange in expression greater than 1.5 -fold for the inoculation trial and 1.3-fold for the PUFA experiment are presented. The gene expression data presented in the tables represent differentially expressed genes within a particular pathway ranked in the first 1000 differentially expressed genes according to the probability value obtained using limma analysis. PUFA comparisons are shown for IL10 ${ }^{-/-}$mice fed PUFA-enriched diets and IL10 ${ }^{-1-}$ mice fed the AIN-76A diet. AIN-76A is the diet common to both inoculation and PUFA experiments; any reference to a control diet in Sections 3 and 4 applies to the AIN-76A diet. 


\section{Results}

\subsection{Inoculation trial}

Mean live weight gain, measured between 5 and 10 weeks of age, was lower in IL $10^{-1-}$ mice compared to C57 mice in the $\mathrm{C}$ and EF.CIF groups (Table 2). EF.CIF inoculated $\mathrm{IL} 10^{-/-}$mice and non-inoculated $\mathrm{IL} 10^{-/-}$ mice kept in conventional condition ( $\mathrm{C}$ group) gained less weight than non-inoculated IL10 $0^{-/-}$mice kept in SPF and EF- or CIF-inoculated IL10 ${ }^{-/-}$mice (Table 2). For the $\mathrm{C} 57$ group, only the EF inoculation significantly reduced $(P<0.05)$ live weight gain compared to non-inoculated C57 mice either in SPF or conventional conditions (Table 2). There was no difference in live weight gain between the non-inoculated C57 mice kept in SPF or conventional conditions (Table 2). All C57 mice inoculated with a bacterial preparation (EF, CIF or EF.CIF) had the same live weight gain (Table 2).

There was no significant difference between the two mouse strains with respect to total intestinal inflammation in the C group (IL10 ${ }^{-/-} 4.7 \pm 3.0$ (S.D.) versus C57 $4.3 \pm 1.4$ (S.D.) $P=0.65$ ). As a result of inoculation, total intestinal HIS was higher in IL10 $0^{-/-}$mice, and this effect was significant in both the EF (IL10 ${ }^{-1-} 12.5 \pm 5.9$ (S.D.) versus C57 $2.3 \pm 1.3$ (S.D.), $P<0.05$ ) and EF.CIF (IL10 ${ }^{-/-} 13.7 \pm 5.4$ (S.D.) versus C57 $4.9 \pm 2.3$ (S.D.), $P<0.05)$ groups. Colon was the most inflamed intestinal section (Fig. 2a), accounting for approximately $60 \%$ of total intestinal HIS in inoculated IL $10^{-/-}$mice. Colon HIS was greater in IL $10^{-1-}$ mice in each of the inoculation groups compared to C57 mice, with the largest difference being in the EF.CIF group (IL10 ${ }^{-/-} 8.1 \pm 3.8$ (S.D.) versus C57 $0.4 \pm 0.5$ (S.D.), $P<0.01$; Fig. $2 b$ ). Colon was therefore used for subsequent microarray analysis.

Initial microarray limma analysis showed a strong effect of inoculation on gene expression; 155 genes were differentially expressed (fold-change $>1.5, P<0.05$ ) in non-inoculated IL10 ${ }^{-/-}$mice compared to noninoculated C57 mice. In contrast, approximately 2000 genes showed differential expression in EF- and EF.CIFinoculated IL $10^{-/-}$mice compared to C57 mice with the same inoculations. For the CIF inoculation, over 1700 genes showed differential expression in $\mathrm{IL} 10^{-1-}$ mice compared to CIF-inoculated C57 mice. IL10 ${ }^{-1-}$ mice inoculated with EF.CIF had the greatest number of differentially expressed genes (2105) when compared with non-inoculated IL10 $0^{-/-}$mice (group C), followed by EF (1641) and CIF (929). When the first 1000 ranked differentially expressed genes were compared between the three inoculation protocols using Ingenuity Pathway
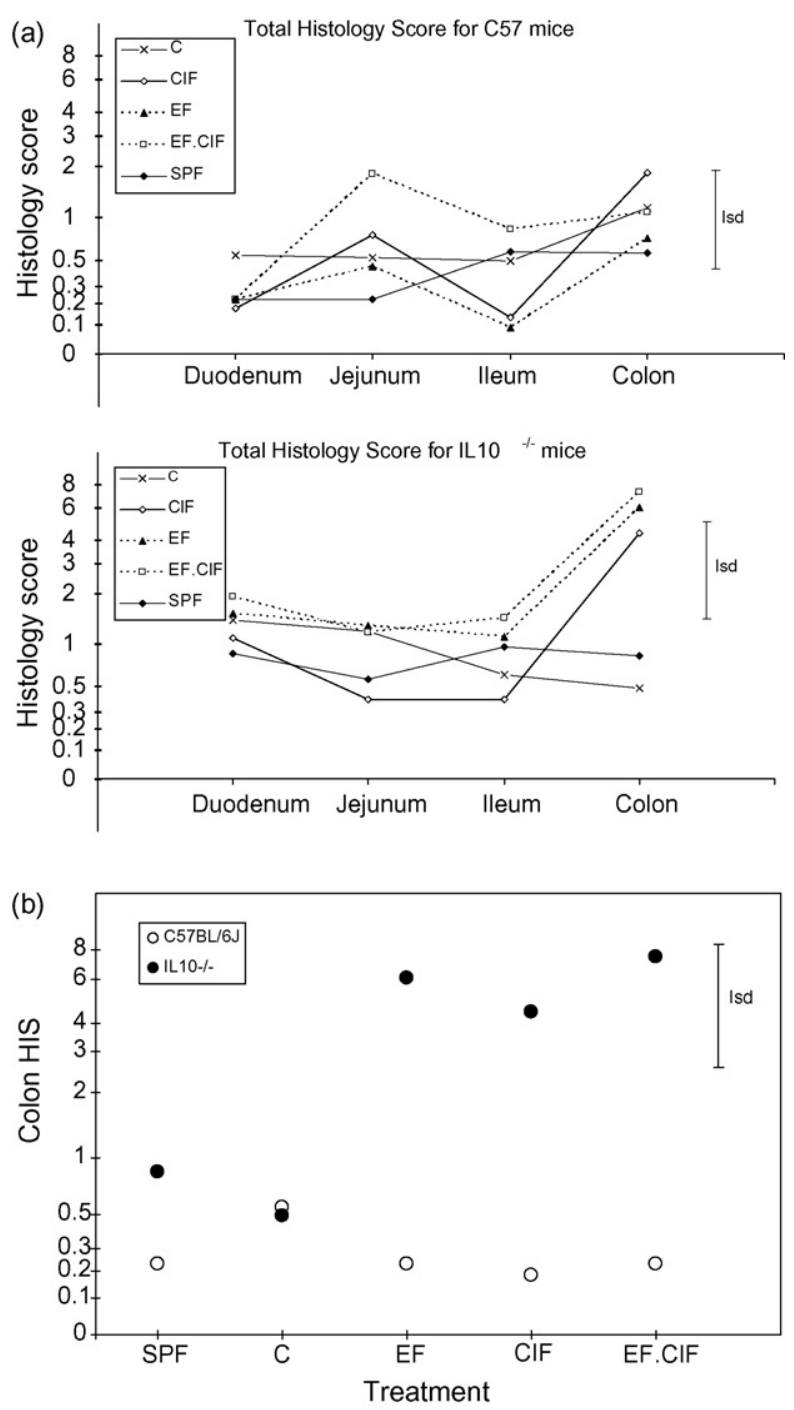

Fig. 2. (a) Total intestinal histological injury score (HIS) and (b) colon HIS of IL $10^{-/-}$and C57 mice at 12 weeks of age after different inoculations at 5 weeks of age. Data represent mean for 5 mice fed the AIN-76A diet, and housed in specific pathogen free (SPF) or conventional $(\mathrm{C})$ conditions, or housed in conventional conditions and orally inoculated with 12 Enterococcus strains (EF), with conventional intestinal flora from normal C57BL/6 mice (CIF), or a 1:1 combination (EF.CIF) at 5 weeks of age. Error bar represents the least significant differences (LSD) for the overall comparison of data.

Analysis, changes in gene expression were largely consistent across the inoculation protocols (Table 3 ).

Clustering of the 155 differentially expressed genes between IL10 ${ }^{-/-}$and C57 mice in the C group using Ingenuity Pathway Analysis identified lipid metabolism, molecular transport and small molecule biochemistry as the most significant pathways that were affected (Table 3). In contrast, cellular movement, haematological system development and function and immune 
Table 2

Mean live weight gain (g) of IL10 $10^{-1-}$ and C57 mice between 5 and 10 weeks of age

\begin{tabular}{|c|c|c|c|}
\hline & \multicolumn{2}{|l|}{ Mouse strain } & \multirow[t]{2}{*}{ Anova $P$-value ( 57 vs. IL $10^{-l-}$ ) } \\
\hline & C57 & $\mathrm{IL}^{-1} 0^{-/-}$ & \\
\hline \multicolumn{4}{|c|}{ Inoculation experiment ${ }^{\mathrm{a}}$} \\
\hline SPF & $5.40 \pm 0.73^{\mathrm{a}}$ & $4.76 \pm 1.25^{\mathrm{a}}$ & $P=0.49$ \\
\hline $\mathrm{C}$ & $5.94 \pm 1.46^{\mathrm{a}}$ & $1.98 \pm 2.30^{\mathrm{b}}$ & $P<0.05$ \\
\hline $\mathrm{EF}$ & $3.86 \pm 0.79^{\mathrm{b}}$ & $2.98 \pm 3.29^{\mathrm{a}, \mathrm{b}}$ & $P=0.59$ \\
\hline CIF & $4.86 \pm 3.04^{\mathrm{a}, \mathrm{b}}$ & $2.03 \pm 1.86^{\mathrm{a}, \mathrm{b}}$ & $P=0.23$ \\
\hline EF.CIF & $5.26 \pm 1.79^{\mathrm{a}, \mathrm{b}}$ & $2.12 \pm 1.45^{\mathrm{b}}$ & $P<0.01$ \\
\hline \multicolumn{4}{|c|}{ PUFA experiment ${ }^{b}$} \\
\hline AIN-76A & $6.09 \pm 2.37^{\mathrm{a}}$ & $4.85 \pm 0.73^{\mathrm{a}}$ & $P=0.36$ \\
\hline $\mathrm{OA}$ & $5.68 \pm 1.87^{\mathrm{a}}$ & $5.20 \pm 0.92^{\mathrm{a}}$ & $P=0.31$ \\
\hline EPA & $5.27 \pm 0.34^{\mathrm{a}}$ & $2.19 \pm 1.36^{\mathrm{b}}$ & $P<0.001$ \\
\hline $\mathrm{AA}$ & $3.82 \pm 0.93^{b}$ & $3.70 \pm 0.96^{\mathrm{c}}$ & $P=0.41$ \\
\hline
\end{tabular}

${ }^{a}$ Data represent mean \pm S.D. for 5 mice fed the AIN-76A diet, and housed in specific pathogen free (SPF) or conventional (C) conditions, or housed in conventional conditions and orally inoculated with 12 Enterococcus strains (EF), with conventional intestinal flora from normal C57 mice (CIF), or a 1:1 combination (EF.CIF). Superscript letters ( $a$ and b) denote C57 and IL10 ${ }^{-1-}$ mice with values significantly different from mice of the same strain under SPF conditions.

${ }^{\mathrm{b}}$ Data represent mean \pm S.D. for six mice fed the AIN-76A diet, or AIN-76A diet supplemented with oleic acid (OA), or the PUFAs eicosapentaenoic acid (EPA) or arachidonic acid (AA). All mice were inoculated at 5 weeks of age with a combination of 12 Enteroccocus strains and conventional intestinal flora from normal C57 mice. Superscript letters $(\mathrm{a}-\mathrm{c})$ that are different indicate a statistical difference $(P<0.05)$ between IL10 ${ }^{-1-}$ mice fed AIN-76A, OA, EPA or AA diets and between C57 mice fed AIN-76A, OA, EPA or AA diets.

response were the most significant pathways altered in IL10 $0^{-1-}$ mice as a result of the EF.CIF inoculation compared to similarly inoculated C57 controls (Table 3). Genes and fold-changes from the immune response, 'inflammatory diseases' and antigen presentation pathways are shown in Tables 4 and 5.

For the antigen presentation pathway, 12 genes were up-regulated in $\mathrm{IL} 10^{-1-}$ mice as a result of EF.CIF inoculation compared to C57 mice receiving the same inoculation; no genes showed evidence of down-regulation in this pathway (Table 5). In the case of immune response, 140 genes were differentially expressed in EF.CIF inoculated IL10 ${ }^{-1-}$ mice compared to EF.CIF inoculated C57 mice. Only the genes within this pathway that were differentially expressed with the EPA- and/or AA-enriched diets are presented in Section 3.3 and in Table 4. For example, the ATP-binding cassette sub-family B member 4 gene (ABCB4) and S100 calcium binding protein A8 gene (S100A8), which ranked in the top 30 according to its limma probability value, are shown in Table 4. In comparison, only 13 immune response genes were differentially expressed in non-inoculated IL10 ${ }^{-/-}$mice compared to the noninoculated C57 mice (data not shown). Seventy-three genes associated with the Ingenuity Pathway Analysis grouping of 'inflammatory diseases' showed differential expression in the EF.CIF $\mathrm{IL}_{10}^{-1-}$ mice compared to EF.CIF C57 mice (including ABCB4, SLP1 and TNFRSFIB; Table 4). This is contrasted with only six genes differentially expressed genes in this pathway for the non-inoculated IL10 ${ }^{-1-}$ mice compared to noninoculated C57 mice (C comparison; data not shown).

\subsection{PUFA trial}

Mean live weight gain from 5 to 10 weeks of age for C57 and IL10 ${ }^{-1-}$ mice in the various dietary treatments is shown in Table 2. Live weight gain was significantly lower in $\mathrm{IL} 10^{-/-}$mice fed the EPA-enriched diet $(P<0.05)$ compared to IL10 ${ }^{-/}$mice fed the AAenriched diet (Table 2). Reduction in live weight gain was also obtained when the IL10 ${ }^{-1-}$ mice fed the EPAenriched diet or AA-enriched diet was compared to the control diets (AIN-76A and OA). There was no difference between IL10 ${ }^{-/-}$mice fed either control diet (Table 2). Within the C57 mice, there was no significant difference in live weight gain between the AIN-76A, OA and EPA diets but $\mathrm{C} 57$ mice fed the AA diet gained less weight than C57 mice fed the AIN-76A, OA and EPA diets (Table 2). There was no significant difference in mean live weight gain between $\mathrm{C} 57$ and $\mathrm{IL} 10^{-1-}$ mice in the AIN-76A, OA or AA diet groups but IL10 ${ }^{-1-}$ mice fed the EPA-enriched diet had a reduced live weight gain compared to C57 mice fed the same diet (Table 2).

Total intestinal HIS among IL10 ${ }^{-1-}$ mice was higher than for C57 mice (IL10 ${ }^{-l-} 9.3 \pm 1.5$ (S.D.) versus C57 $1.3 \pm 0.4$ (S.D.), $P<0.01$ ) with colon being the most 
Table 3

Summary of differentially expressed genes in colon tissue of IL-10 $10^{-1-}$ mice compared to C57 mice, and in IL10 ${ }^{-/-}$mice inoculated with EF.CIF in response to dietary PUFAs, and the key functions represented by these genes

\begin{tabular}{|c|c|c|c|c|}
\hline \multirow[t]{2}{*}{ Comparison } & \multicolumn{3}{|c|}{ Differentially expressed genes } & \multirow[t]{2}{*}{ Major functions (number differentially expressed) } \\
\hline & Increase & Decrease & Total & \\
\hline \multicolumn{5}{|l|}{ Inoculation experiment } \\
\hline $\mathrm{C}\left(\mathrm{IL} 10^{-1-}\right.$ vs. C57) & 104 & 51 & 155 & $\begin{array}{l}\text { Lipid metabolism (11) } \\
\text { Molecular transport (7) } \\
\text { Small molecule biochemistry (18) }\end{array}$ \\
\hline $\mathrm{EF}\left(\mathrm{IL} 10^{-1-}\right.$ vs. C57) & 1020 & 1222 & 2242 & $\begin{array}{l}\text { Cellular movement (110) } \\
\text { Haematological system development and function (127) } \\
\text { Immune response (140) }\end{array}$ \\
\hline CIF (IL10 ${ }^{-1-}$ vs. C57) & 864 & 839 & 1703 & $\begin{array}{l}\text { Cellular movement (109) } \\
\text { Haematological system development and function (129) } \\
\text { Immune response (147) }\end{array}$ \\
\hline EF.CIF (IL10 ${ }^{-/-}$vs. C57) & 967 & 1032 & 1999 & $\begin{array}{l}\text { Cellular movement (107) } \\
\text { Haematological system development and function (115) } \\
\text { Immune response (140) }\end{array}$ \\
\hline IL10 ${ }^{-/-}$(EF vs. C) & 633 & 1008 & 1641 & $\begin{array}{l}\text { Cellular movement (98) } \\
\text { Haematological system development and function (104) } \\
\text { Immune response (120) }\end{array}$ \\
\hline IL10 ${ }^{-1-}$ (CIF vs. C) & 450 & 479 & 929 & $\begin{array}{l}\text { Immune response (127) } \\
\text { Cellular movement (110) } \\
\text { Haematological system development and function (116) }\end{array}$ \\
\hline IL10 ${ }^{-/-}$(EF.CIF vs. C) & 604 & 1501 & 2105 & $\begin{array}{l}\text { Cellular movement (97) } \\
\text { Haematological system development and function (106) } \\
\text { Immune response (118) }\end{array}$ \\
\hline \multicolumn{5}{|l|}{ PUFA experiment } \\
\hline AIN-76 (IL10 ${ }^{-1-}$ vs C57) & 1046 & 889 & 1935 & $\begin{array}{l}\text { Inflammatory disease (94) } \\
\text { Haematological system development and function (121) } \\
\text { Immune response (143) }\end{array}$ \\
\hline $\mathrm{IL}^{-1}{ }^{-I}$ (OA vs. AIN-76A) & 264 & 257 & 521 & $\begin{array}{l}\text { Cellular growth and proliferation (15) } \\
\text { Cell-to-cell signaling and interaction (31) } \\
\text { Immune response (10) }\end{array}$ \\
\hline IL10 ${ }^{-1-}$ (EPA vs. AIN-76A) & 597 & 389 & 986 & $\begin{array}{l}\text { Cell-to-cell signaling and interaction (42) } \\
\text { Inflammatory diseases (15) } \\
\text { Amino acid metabolism (4) }\end{array}$ \\
\hline IL10 ${ }^{-1-}$ (AA vs. AIN-76A) & 852 & 575 & 1427 & $\begin{array}{l}\text { Cell-to-cell signaling and interaction (79) } \\
\text { Inflammatory diseases (49) } \\
\text { Amino acid metabolism (8) }\end{array}$ \\
\hline
\end{tabular}

Data represent numbers of differentially expressed genes for each comparison, calculated using limma analysis within the Bioconductor framework. For the inoculation experiment, a fold-change of $>1.5$ and false discovery rate control of $P<0.05$ were used as filtering criteria; for the PUFA experiment, fold-change $>1.3$ and $P$-value $<0.05$. The most significant functions were identified using Ingenuity Pathway Analysis Software. Total RNA from colon tissue was used for microarray hybridization to Agilent Technologies 44k (G4122-60510) mouse 60mer oligonucleotide arrays. For the inoculation (EF.CIF-inoculated IL10 ${ }^{-1-}$ vs. similarly treated C57 mice) and PUFA (PUFA-fed IL10 ${ }^{-1-}$ vs. AIN-76A-fed IL10 ${ }^{-1-}$ mice) experiments data represent mean values from two pools of RNA for each mouse strain, with RNA from two and three mice, respectively, in each pool.

inflamed intestinal tissue (Fig. 3a). Intestinal inflammation scores were mainly derived from inflammatory cell infiltration (75\%, monocytes and neutrophils) and to a lesser extent, tissue destruction (20\%, enterocyte loss and edema) and tissue repair (5\%, hyperplasia). IL10 ${ }^{-l-}$ mice on the EPA and AA diets had at least $40 \%$ lower colonic HIS scores $(P<0.05)$ than IL10 ${ }^{-1-}$ mice on control diets, AIN-76A and OA (Fig. 3b). There was also a greater variation in HIS in the colon of $\mathrm{IL} 10^{-/-}$mice compared to $\mathrm{C} 57$ mice (Fig. 3b). 
Table 4

Differentially expressed immune response and 'inflammatory diseases' genes in colon tissue of IL-10 ${ }^{-1-}$ mice compared to C57 mice (both with EF.CIF bacterial inoculation), and in PUFA-fed EF.CIF-inoculated IL10 ${ }^{-/-}$mice compared to similarly inoculated IL10 ${ }^{-/-}$mice fed AIN-76A

\begin{tabular}{|c|c|c|c|c|c|}
\hline \multirow[t]{2}{*}{ Gene name } & \multirow[t]{2}{*}{ Symbol } & \multirow[t]{2}{*}{ Refseq ID } & \multicolumn{3}{|l|}{ Fold-change } \\
\hline & & & $\begin{array}{l}\text { EF.CIF IL10 } 10^{-1-} \\
\text { vs. C57 }\end{array}$ & $\begin{array}{l}\text { IL10-1- EPA } \\
\text { vs. AIN-76A }\end{array}$ & $\begin{array}{l}\text { IL10 } 0^{-1-} \text { AA vs. } \\
\text { AIN-76A }\end{array}$ \\
\hline $\begin{array}{l}\text { ATP-binding cassette, subfamily B, member } \\
4\end{array}$ & $\mathrm{ABCB} 4$ & NM_008830 & -4.1 & +2.8 & +1.7 \\
\hline Calpastatin & CAST & NM_009817 & +1.9 & +1.4 & +1.3 \\
\hline CD38 molecule & CD38 & NM_007646 & +3.3 & $+1.7^{\mathrm{NS}}$ & +2.2 \\
\hline Fibroblast growth factor 7 & FGF7 & NM_008008 & $+1.1^{\mathrm{NS}}$ & $-1.3^{\mathrm{NS}}$ & -1.6 \\
\hline Inducible T-cell costimulator ligand & ICOSLG & NM_015790 & $+1.1^{\mathrm{NS}}$ & $+1.4^{\mathrm{NS}}$ & +1.6 \\
\hline Interleukin 6 & IL6 & NM_031168 & $-1.2^{\mathrm{NS}}$ & $-1.1^{\mathrm{NS}}$ & -2.7 \\
\hline Monoglyceride lipase & MGLL & NM_011844 & -2.3 & +2.1 & +1.8 \\
\hline Myosin, light polypeptide kinase & MYLK & NM_139300 & -2.7 & +1.4 & +1.4 \\
\hline $\begin{array}{l}\text { Peroxisome proliferative activated receptor, } \\
\text { alpha }\end{array}$ & $\operatorname{PPAR} \alpha$ & NM_011144 & -2.3 & +1.9 & +1.7 \\
\hline $\begin{array}{l}\text { Peroxisome proliferative activated receptor, } \\
\text { gamma, coactivator } 1 \text {, alpha }\end{array}$ & PPARGC1A & AK032149 & $-1.2^{\mathrm{NS}}$ & $+1.3^{\mathrm{NS}}$ & +1.4 \\
\hline Protease, serine, 23 & PRSS23 & NM_029614 & -3.8 & $+2.0^{\mathrm{NS}}$ & +2.8 \\
\hline $\begin{array}{l}\text { Prostaglandin-endoperoxide synthase } 2 \\
\quad(\text { Cox-2) }\end{array}$ & PTGS2 & NM_011198 & $+1.5^{\mathrm{NS}}$ & $-1.1^{\mathrm{NS}}$ & -3.1 \\
\hline S100 calcium binding protein A8 & S100A8 & NM_013650 & +8.9 & $+1.4^{\mathrm{NS}}$ & -2.8 \\
\hline Secretory leukocyte peptidase inhibitor & SLPI & NM_011414 & +6.0 & +1.7 & $-1.1^{\mathrm{NS}}$ \\
\hline Tumor necrosis factor, alpha & $\mathrm{TNF} \alpha$ & NM_013693 & +2.3 & $-1.1^{\mathrm{NS}}$ & -1.5 \\
\hline $\begin{array}{l}\text { Tumor necrosis factor receptor superfamily, } \\
\text { member 1B }\end{array}$ & TNFRSF1B & NM_011610 & +1.9 & -1.3 & $-1.3^{\mathrm{NS}}$ \\
\hline
\end{tabular}

Data represent the fold-change in gene expression for the particular comparison, calculated using limma analysis according to the Bioconductor framework and clustered in pathways according the Ingenuity Pathway Analysis Software. Total RNA from colon tissue was used for microarray hybridization to Agilent Technologies 44k (G4122-60510) mouse 60mer oligonucleotide arrays. A NS superscript means the reported fold-change was not significant between the two groups being compared. For the inoculation (EF.CIF-inoculated IL $10^{-1-}$ vs. similarly treated C57 mice) and PUFA (PUFA-fed IL10 $10^{-l-}$ vs. AIN-76A-fed IL10 ${ }^{-l-}$ mice) experiments data represent mean values from two pools of RNA for each mouse strain, with RNA from two and three mice, respectively, in each pool.

Gene expression analysis using limma and pathway clustering using Ingenuity Pathway Analysis Software revealed 'cell-to-cell signaling and interaction', 'inflammatory diseases' and 'amino acid metabolism' as the key functions affected in IL10 $10^{-1-}$ mice fed EPA- and AA-enriched diets (Table 3). This paper focused on the expression data for genes in the ranked first 1000 list that are significant according to the criteria stated in Section 2.7 and that clustered in the 'immune response' and 'inflammatory diseases' pathways (Table 4). The gene list for EF.CIF IL10 ${ }^{-/}$versus C57 comparison presented in Table 4 is data from the inoculation trial as similar results were obtained from the PUFA trial for that comparison.

\subsection{Specific differentially expressed genes in the inoculation or PUFA trial}

The expression of the monoglyceride lipase gene (MGLL) which is involved in lipid metabolism and inflammatory responses was down-regulated in IL $10^{-/-}$ mice compared to C57 mice, both fed the control diet but MGLL expression was up-regulated in the IL $10^{-1-}$ mice fed PUFA diets (Table 4). The S100A8 protein plays a role in inflammatory responses and its gene expression was up-regulated by 8.9 -fold in IL10 $0^{-1}$ mice fed the control diet compared to C57 mice fed the same diet. In contrast, the expression of the S100A8 gene showed a significant down-regulation in the IL10 $0^{-/-}$mice fed the AA-enriched diet, but its expression was unchanged in the EPA-fed IL10 ${ }^{-1-}$ mice (Table 4). The expression of the prostaglandin-endoperoxide synthase 2 gene (PTGS2, also named COX-2), which is a major mediator of inflammation, was unchanged in $\mathrm{IL} 10^{-/-}$mice fed the control diet, but when this diet was enriched with AA, PTGS2 gene expression was down-regulated.

Table 4 also shows which genes involved in innate immune responses and T-cell responses had altered expression as a consequence of the dietary PUFA treatments. This includes genes such as tumor necrosis factor alpha (TNF $\alpha$; only significant for the AA-enriched diet) and its receptor (tumor necrosis factor receptor super- 
Table 5

'Antigen presentation pathway' genes differentially expressed in colon tissue of EF.CIF-inoculated IL-10 ${ }^{-/-}$mice compared with EF.CIF-inoculated C57 mice

\begin{tabular}{|c|c|c|c|}
\hline Gene name & Symbol & Refseq ID & $\begin{array}{l}\text { EF.CIF IL10 } \\
\text { vs. EF.CIF C57 }\end{array}$ \\
\hline CD74 molecule, MHC Class II invariant chain & $\mathrm{CD} 74$ & NM_010545 & +5.7 \\
\hline Histocompatability 2, Q region locus 1 & $\mathrm{H} 2-\mathrm{Q} 1$ & NM_010390 & +1.5 \\
\hline MHC Class II, DM alpha & HLA-DMA & NM_010386 & +2.9 \\
\hline MHC Class II, DM beta & HLA-DMB & NM_010387 & +7.1 \\
\hline MHC Class II, DQ alpha 1 & HLA-DQA1 & NM_010378 & +4.4 \\
\hline MHC Class II, DQ beta 2 & HLA-DQB2 & NM_207105 & +6.3 \\
\hline MHC Class II, DR beta 1 & HLA-DRB1 & NM_010382 & +4.6 \\
\hline HLA-G histocompatability antigen, Class I, G & HLA-G & NM_010391 & +1.8 \\
\hline $\begin{array}{l}\text { Proteasome (prosome, macropain) subunit, beta type, } 8 \\
\quad \text { (large multifunctional peptidase } 7 \text { ) }\end{array}$ & PSMB8 & NM_010724 & +3.9 \\
\hline $\begin{array}{l}\text { Proteasome (prosome, macropain) subunit, beta type, } 9 \\
\quad \text { (large multifunctional peptidase 2) }\end{array}$ & PSMB9 & NM_013585 & +3.8 \\
\hline Transporter 1, ATP-binding cassette, sub-family B & TAP1 & NM_013683 & +2.5 \\
\hline Transporter 1, ATP-binding cassette, sub-family B & TAP2 & NM_011530 & +1.7 \\
\hline
\end{tabular}

Data represent the fold-change of gene expression for the particular comparison, calculated using limma analysis according to the Bioconductor framework and clustered in pathways using Ingenuity Pathway Analysis Software. Total RNA from colon tissue was used for microarray hybridization to Agilent Technologies 44k (G4122-60510) mouse 60mer oligonucleotide arrays. Data represent mean values from two pools of RNA for each mouse strain, with RNA from two and three mice, respectively, in each pool.

family, member 1B (TNFRF1B); only significant for the EPA-enriched diet), which were over-expressed in IL $10^{-/-}$mice fed the control diet compared to C57 mice fed the same diet, but under-expressed in IL $10^{-1-}$ mice fed either PUFA diet (Table 4). There was no change in interleukin 6 (IL6) expression in IL10 $10^{-1-}$ mice fed the control diet, but this gene showed a lower expression in mice fed the AA-enriched diet (not statistically significant for the EPA-enriched diet). The secretory leukocyte peptidase inhibitor (SLPI) gene, expression

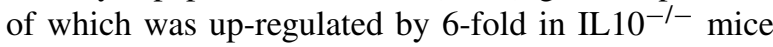
compared to $\mathrm{C} 57$ mice, was still up-regulated but by only 1.7 -fold in IL10 ${ }^{-/-}$mice fed the EPA-enriched diet, but decreased in IL10 ${ }^{-/-}$mice fed the AA-enriched diet. The expression of the inducible T-cell costimulator ligand (ICOSLG) gene was unchanged in the IL10 $10^{-/-}$ mice fed the control diet, but up-regulated in IL10 $10^{-/}$ mice fed the PUFA diets (Table 4).

Other genes involved in immune response and inflammation that were up-regulated in IL $10^{-1-}$ mice fed either PUFA-enriched diet were the ABCB4 gene (also named multidrug resistance gene 2 (mouse); down-regulated in IL10 ${ }^{-/-}$mice compared to C57 mice fed the control diet) and the PPAR $\alpha$ gene (Table 3 ). The other isoform of the PPAR gene, PPAR $\gamma$, was down-regulated in IL $10^{-/-}$ mice fed the control diet but unchanged with the PUFAenriched diet (data not shown). In contrast, myosin light polypeptide kinase (MYLC) and protease serine 23 genes were under-expressed in the IL $10^{-/-}$mice fed the control diet but over-expressed when the IL10 ${ }^{-/-}$ mice were fed the PUFA diets (Table 4). Expression of the genes encoding calpastatin and CD38 molecule were up-regulated irrespective of the strain effect or dietary PUFAs (Table 4).

\section{Discussion}

Our study shows for the first time that oral inoculation of IL10 $10^{-1-}$ mice (C57 background) with an EF.CIF bacterial preparation at 5 weeks of age results in increased and consistent inflammation compared to non-inoculated $\mathrm{IL}_{10}{ }^{-/-}$mice, with the most highly inflamed area of intestine being the colon. These histological changes were accompanied by significant changes in expression of genes involved in 'immune response', 'inflammatory diseases' and 'antigen presentation' by 11 weeks of age. These results support the suggestion that our refined IL $10^{-/-}$mouse model shows characteristics of chronic inflammatory diseases, such as a dysregulated immune response acting in combination with inflammatory mechanisms that can cause tissue damage. The up-regulation of antigen presentation genes is consistent with increased expression of HLA Class II molecules that typically occurs in IBD in humans [29]. HLA Class II genes have been associated with risk of IBD in a number of populations [30,31] (reviewed in ref. [32]). In addition, MHC Class II antigen expression 
(a)
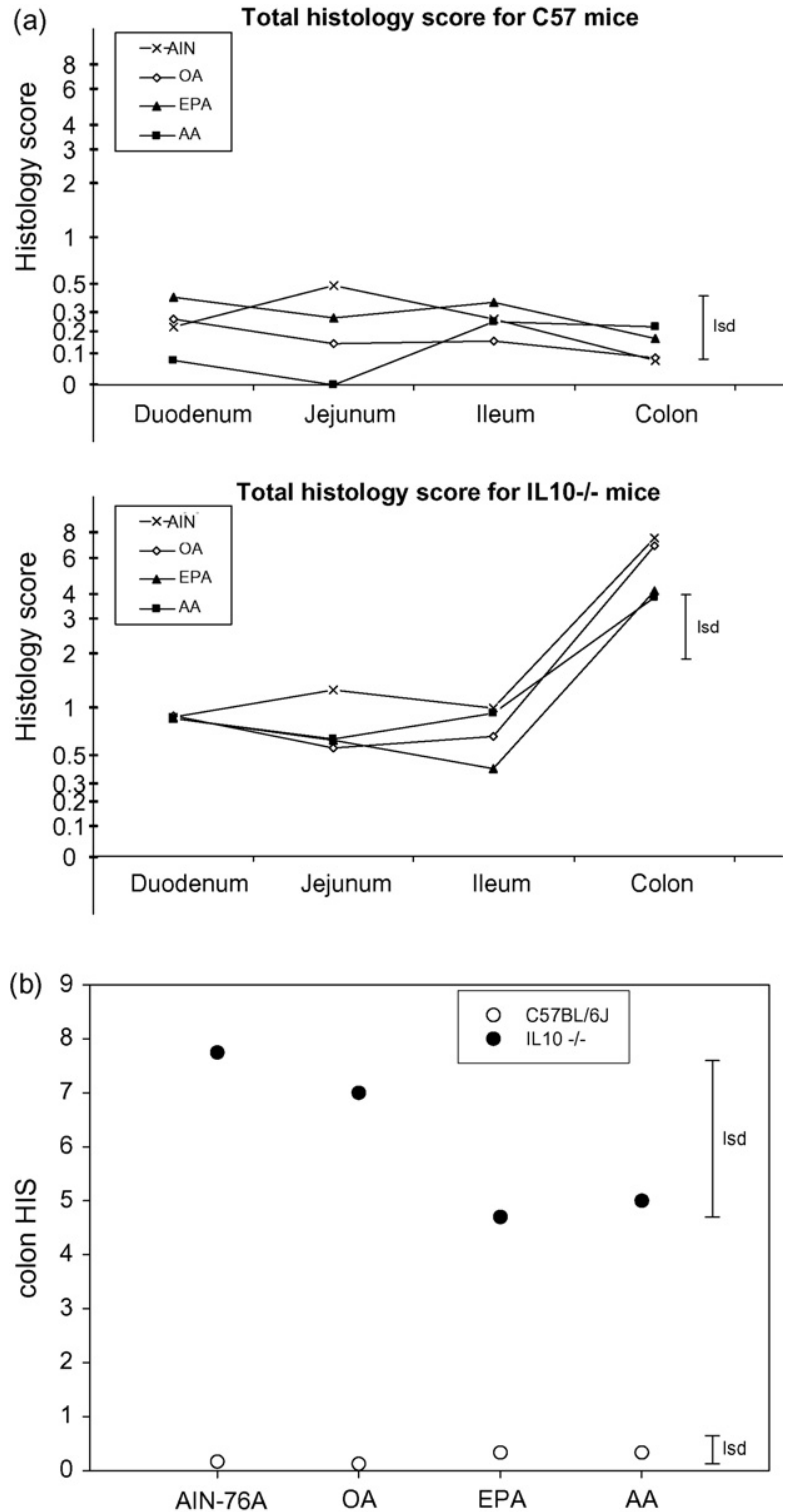

Fig. 3. (a) Total intestinal histological injury score (HIS) and (b) colonic HIS of IL10 ${ }^{-1-}$ and C57BL/6J mice at 11 weeks of age after PUFA treatments from 5 to 11 weeks of age. Data represent means for 6 mice fed AIN-76A diet, or AIN-76A diet supplemented with oleic acid (OA) or the PUFAs eicosapentaenoic acid (EPA) or arachidonic acid (AA). AIN-76A and OA are both control diets. Bars represent the least significant differences (LSD) for each mouse strain. All mice were inoculated at 5 weeks of age with a combination of 12 Enteroccocus strains and conventional intestinal flora from normal C57BL/6 mice.

has previously been observed in the colon epithelial cells of 3-6 month-old IL10 ${ }^{-1-}$ mice [16]. Overall, our findings indicate that this refined IL $10^{-/-}$mouse model represents an improved model of IBD, due to increased intestinal inflammation as a result of the inoculation procedure. This model is therefore more suitable for testing various food components to identify those with potential beneficial effects for IBD patients.

Using this model, we have shown that dietary EPA and AA lowered the colonic inflammation observed in IL $10^{-1-}$ mice. Unexpectedly, both AA- and EPA-fed IL $10^{-/-}$mice lost more body weight than IL10 ${ }^{-/-}$mice fed the control diets (AIN-76A and OA diets), but AAfed IL10 $0^{-1-}$ mice did not lose as much body weight as those fed EPA. Why growth was reduced with the EPA diet is unclear. Improved colonic health (occurrence and incidence of colonic tumors) in Apc(min) mice fed an EPA-enriched diet similar to this study has also been reported in the literature [23]. However, in that study, a similar diet enriched with AA increased the occurrence and incidence of colonic tumors in these mice compared to OA-enriched diet [23] whereas we did not observe similar effects of AA on colonic inflammation.

In IL10 $0^{-/-}$mice fed the control diet, expression of PTGS2, a gene coding for an enzyme that catalyses the formation of prostaglandins from $\mathrm{AA}$, was unchanged. This is in contrast with literature reports showing that PTGS2 is over-expressed in sites of early inflammation [33]. Results of another study by our group indicated that EF.CIF IL10 ${ }^{-1-}$ mice fed a control diet similar to the control (AIN-76A) diet used in this study showed early signs of inflammation at 8 weeks of age [24] so it is possible that an early increase in PTGS2 gene expression occurred but did not persist to 11 weeks of age. When AA-enriched diet was fed to IL-10 $10^{-1-}$ mice, expression of the PTGS2 gene was down-regulated at 11 weeks of age. It has been shown in vitro that unsaturated fatty acids such as EPA are the most potent inhibitors of AA-induced PTGS2 protein activity [34] and lipopolysaccharide-induced PTGS2 protein expression [35]. In Lee et al.'s study, lipopolysaccharide-induced PTGS2 protein expression was also inhibited by $n-6$ PUFA such as AA but to a lesser degree than EPA and DHA while saturated fatty acids induced its expression [35]. As PTGS2 catalyses the formation of proinflammatory prostaglandin E2 from AA, higher dietary AA should induce colonic inflammation but this was not the observation in IL10 ${ }^{-/-}$mice fed the AA-enriched diet. Why AA reduced the colonic expression of PTGS2 and inflammation in $\mathrm{IL}_{10}^{-/-}$mice in this study is unclear. It has been shown that prostaglandin E2 also suppresses production of TNF $\alpha$ and IL 6 by monocytes and macrophages, and inhibits 5-lipoxygenase, thereby interfering with leukotriene $\mathrm{X} 4$ production; in this way, AA could give rise to anti-inflammatory lipoxins [36].

In IL $10^{-1-}$ mice fed the control diet, there was a four-fold down-regulation of ABCB4 in colonic tissues. 
Another gene which is part of the ABC family, ABCB1, was also down-regulated in the same mice (data not shown). Like several other $\mathrm{ABC}$ transporters, $\mathrm{ABCB} 4$ is a lipid translocator and it has been shown to translocate phosphatidylcholine from the inner to the outer leaflet of the canalicular membrane of hepatocytes; ABCB4 deficiency results in severe liver disease [37]. In colonic tissue, to our knowledge, there is no report of ABCB4 gene expression in the literature. As in this study, chronic colonic inflammation as observed in IBD patients and in animal models of IBD can result in a down-regulation of other $\mathrm{ABC}$ genes, such as $\mathrm{ABCB} 1 \mathrm{~A}$ and $\mathrm{ABCB} 1 \mathrm{~B}$ [38-40] suggesting a dysregulation of the $A B C$ transporters during inflammation. In contrast, PUFA-enriched diets resulted in an up-regulation of the $\mathrm{ABCB} 4$ gene and likely, in a more optimal lipid translocation.

Furthermore, the expression of the S100A8 gene that codes for a calcium binding protein was up-regulated by nine-fold in $\mathrm{IL} 10^{-/-}$mice fed the control diet. Murine S100A8 is a potent chemo-attractant (calcium binding protein) and its up-regulation has been associated with a number of acute and chronic inflammatory conditions and may protect against oxidative tissue damage [41]. In contrast, the down-regulation of the S100A8 gene observed in IL10 ${ }^{-1-}$ mice fed the AA diet could be explained by the additional free extracellular AA available to the inflamed tissue reducing the need for intracellular AA to be transported through the S100A8/A9-AA complex at the site of inflammatory lesions [42].

Down-regulation of the expression of FGF7 (also called keratinocyte growth factor) was observed in the colon of IL10 $10^{-I}$ mice fed AA-enriched diet but its expression was unchanged in the colon of IL $10^{-1-}$ and C57 mice fed the control diet. FGF7 is involved in epithelial regeneration, and could be less active in IL $10^{-/-}$mice fed AA because of the reduced colonic inflammation and tissue damage observed in this diet group, indicating a reduced requirement for regeneration. No mRNA for the FGF7 gene was detected in colon of dextran sodium sulfate challenged pigs (another model of IBD) fed a control diet or diets supplemented with $n-3$ PUFA (no data was available for $n-6$ PUFA) despite increased colonic tissue regeneration [43]. This result indicates that epithelial regeneration may in this case be FGF7-independent although its occurrence might depend on other growth factors and cytokines [44]. In the Bassaganya-Riera and Hontecillas study [43], an $n-3$ PUFA-enriched diet failed to protect from IBD, and instead promoted remission from IBD possibly by activating PPAR $\delta$. The same study showed that a mixture of conjugated linoleic acid and $n-3$
PUFAs accelerated recovery from IBD by activating PPAR $\delta$ and up-regulating the expression of FGF7 in the colon, while CLA alone delayed the onset of IBD by activating another isoform of PPAR, PPAR $\gamma$. These results together might indicate a synergistic regulation of inflammatory pathways by unsaturated lipids.

The colonic expression of PPAR $\alpha$ was downregulated by at least two-fold in $\mathrm{IL} 10^{-/-}$mice fed the control diet but up-regulated when fed the PUFAenriched diets. PPAR molecules have three isoforms $(\alpha, \gamma, \delta)$ and act as a sensor for intracellular nutrient concentration through a nuclear receptor, thus regulating gene expression [36]. Up-regulation of PPAR $\alpha$ by AA corroborates previous findings where PPAR isoforms in the intestine can be activated by PUFAs to ameliorate inflammatory disease severity [43]. PPAR $\alpha$ gene activation is not specific to PUFA as a large number of fatty acids have been shown to activate this gene [36]. PPAR $\alpha$ genes can be activated by lipids or their metabolites (e.g. oxidized phospholipids, raised AA concentrations or eicosanoids) following binding to the PPAR receptor [36]. For example, PPAR $\alpha$ could have been activated indirectly through the increased AA concentration as a result of feeding the AA-enriched diet, or because of eicosanoid formation from AA via the CYP4A family [45], although the expression of the genes coding for the CYP4As was unchanged in IL10 ${ }^{-/-}$mice fed this diet (data not shown). In contrast to PPAR $\alpha$, PPAR $\gamma$ has selectivity for unsaturated fatty acids including PUFAs [36]. However, in IL10 ${ }^{-/-}$ mice fed PUFA-enriched diet, PPAR $\gamma$ expression was unchanged.

The beneficial effect of PUFAs on colonic inflammatory responses seen in this study agrees with literature reports which show that PUFAs have immunomodulatory effects on cells of the immune system [36]. The results from the current study therefore suggest that, contrary to the proposed hypothesis, dietary AA supplementation had a beneficial effect on intestinal inflammation similar to that of EPA, and showed similar gene expression results to those of CLA reported in inflamed pigs [43]. AA activated colonic PPAR $\alpha$ but also diminished the production of genes involved in immunomodulation and inflammation (TNF $\alpha$, IL6, etc.). Comparing gene expression changes in tissues of animals fed $n-3$ versus $n-6$ PUFAs diets often reveals only minor differences [36]. However, the preliminary results from this study suggest that the refined mouse model of IBD developed here, IL10 ${ }^{-1-}$ mice inoculated with EF.CIF, allows important gene expression changes occurring as a result of $n-3$ and $n-6$ PUFA-enriched diets to be identified. 


\section{Conclusions}

The studies described in this paper show the development of an improved mouse model of inflammation, and one example of using this model to investigate food components with potential for the amelioration of IBD. These results represent early steps in the development of foods which may interact with an individual's genetic make-up in a beneficial manner, to improve health and well-being.

\section{Acknowledgements}

Nutrigenomics New Zealand is a collaboration between AgResearch Limited, Crop \& Food Research, HortResearch and The University of Auckland largely funded by the Foundation of Research, Science and Technology (FRST). Matthew Barnett is funded by FRST Postdoctoral Fellowship AGRX0504. Bianca Knoch's Ph.D. Fellowship is funded by Nutrigenomics New Zealand. The authors acknowledge the important contribution to these studies of Dr. William Zhu (histology), Dr. Marcus Davy (bioinformatic analysis), Zaneta Park-Ng (bioinformatic and statistical analyses), John Koolaard (statistical analysis), Dr. Adrian Cookson (inoculation protocol), Kate Broadley (assistance with microarrays), Ric Broadhurst (small animal expertise), Kim Oden (assistance with animal experiments), Philippa Grainger (assistance with animal experiments), Bruce Sinclair (assistance with animal experiments) and Dr. Scott Knowles (a Ph.D. supervisor of Bianca Knoch).

\section{References}

[1] F. Guarner, J.R. Malagelada, Gut flora in health and disease, Lancet 360 (2003) 512-519.

[2] P. Bourlioux, B. Koletzko, F. Guarner, V. Braesco, The intestine and its microflora are partners for the protection of the host, Am. J. Clin. Nutr 78 (2002) 675-683.

[3] M.S. Balda, K. Matter, Tight junctions, J. Cell Sci. 111 (1998) 541-547.

[4] B. Deplancke, H.R. Gaskins, Microbial modulation of innate defense: goblet cells and the intestinal mucus layer, Am. J. Clin. Nutr. 73 (2001) 1131S-1141S.

[5] C. Nagler-Anderson, Man the barrier! Strategic defences in the intestinal mucosa, Nat. Rev. Immunol. 1 (2001) 59-67.

[6] M. Rimoldi, M. Chieppa, P. Larghi, M. Vulcano, P. Allavena, M. Rescigno, Monocyte-derived dendritic cells activated by bacteria or by bacteria-stimulated epithelial cells are functionally different, Blood 106 (2005) 2818-2826.

[7] H. Clevers, At the crossroads of inflammation and cancer, Cell 118 (2004) 671-674.

[8] E.J. Irvine, J.K. Marshall, Increased intestinal permeability precedes the onset of Crohn's disease in a subject with familial risk, Gastroenterology 119 (2000) 1740-1744.
[9] D. Hollander, Crohn's disease, TNF-alpha, and the leaky gut. The chicken or the egg? Am. J. Gastroenterol. 97 (2002) 1867-1868.

[10] R. Aharoni, B. Kayhan, O. Brenner, H. Domev, G. Labunskay, R. Arnon, Immunomodulatory therapeutic effect of glatiramer acetate on several murine models of inflammatory bowel disease, J. Pharmacol. Exp. Ther. 318 (2006) 68-78.

[11] A.R. Jurjus, N.N. Khoury, J.-M. Reimund, Animal models of inflammatory bowel disease, J. Pharmacol. Toxicol. Methods 50 (2004) 81-92.

[12] D.M. Rennick, M.M. Fort, Lessons from genetically engineered animal models. XII. IL-10-deficient (IL-10 ${ }^{-/}$) mice and intestinal inflammation, Am. J. Physiol. 278 (2000) G829-G833.

[13] R. Kühn, J. Löhler, D. Rennick, K. Rajewsky, W. Müller, Interleukin-10-deficient mice develop chronic enterocolitis, Cell 75 (1993) 263-274.

[14] K.W. Moore, A. O'Garra, R. de Waal Malefyt, P. Vieira, T.R. Mosmann, Interleukin-10, Annu. Rev. Immunol. 11 (1993) 165-190.

[15] K.W. Moore, R. de Waal Malefyt, R.L. Coffman, A. O'Garra, Interleukin-10 and the interleukin-10 receptor, Annu. Rev. Immunol. 19 (2001) 683-765.

[16] D.J. Berg, N. Davidson, R. Kühn, W. Muller, S. Menon, G. Holland, L. Thompson-Snipes, M.W. Leach, D. Rennick, Enterocolitis and colon cancer in interleukin-10-deficient mice are associated with aberrant cytokine production and CD4 + TH1-like responses, J. Clin. Invest. 98 (1996) 1010-1020.

[17] J. McCarthy, L. O’Mahony, L. O’Callaghan, B. Sheil, E.E. Vaughan, N. Fitzsimons, J. Fitzgibbon, G.C. O'Sullivan, B. Kiely, J.K. Collins, F. Shanahan, Double blind, placebo controlled trial of two probiotic strains in interleukin 10 knockout mice and mechanistic link with cytokine balance, Gut 52 (2003) 975-980.

[18] R.K. Sellon, S. Tonkonogy, M. Schultz, L.A. Dieleman, W. Grenther, E. Balish, D.M. Rennick, R.B. Sartor, Resident enteric bacteria are necessary for development of spontaneous colitis and immune system activation in interleukin-10-deficient mice, Infect. Immun. 66 (1998) 5224-5231.

[19] M.P.G. Barnett, S.T. Zhu, W. Laing, W.C. McNabb, N.C. Roy, Cytochrome $\mathrm{P} 450$ monooxygenase genes are over-expressed in jejunum mucosa of interleukin 10 knockout mouse, a model of inflammatory bowel disease, in: Beyond Genome Conference, San Francisco, USA, 2005.

[20] E. Balish, T. Warner, Enterococcus faecalis induces inflammatory bowel disease in interleukin-10 knockout mice, Am. J. Pathol. 160 (2002) 2253-2257.

[21] M.J. James, R.A. Gibson, L.G. Cleland, Dietary polyunsaturated fatty acids and inflammatory mediator production, Am. J. Clin. Nutr. 71 (2000) 343S-348S.

[22] Subcommittee on Laboratory Animal Nutrition, Committee on Animal Nutrition, Board on Agriculture, National Research Council, Nutrient Requirements of the Mouse, in: Nutrient Requirements of Laboratory Animals, fourth revised ed., National Academies Press, Washington, 1995, pp., 80-102.

[23] J. Whelan, M.F. McEntee, Dietary $n-6$ PUFA and intestinal tumorigenesis, J. Nutr. 134 (2004) 3421-3424.

[24] B. Knoch, M.P.G. Barnett, S.T. Zhu, R. Broadhurst, W.C. McNabb, S.O. Knowles, C.E. Ugarte, N.C. Roy, Establishment of the optimal tissue sampling time for the interleukin-10 knockout mouse inoculated with endogenous intestinal bacteria, a model of inflammatory bowel disease, Reprod. Nutr. Dev. 46 (2006) S71-S72.

[25] E.I. Park, E.A. Paisley, H.J. Mangian, D.A. Swartz, M.X. Wu, P.J. O'Morchoe, S.R. Behr, W.J. Visek, J. Kaput, Lipid level and type alter stearoyl CoA desaturase mRNA abundance differently 
in mice with distinct susceptibilities to diet-influenced diseases, J. Nutr. 127 (1997) 566-573.

[26] M. Kruschewski, T. Foitzik, A. Perez-Canto, A. Hubotter, H.J. Buhr, Changes of colonic mucosal microcirculation and histology in two colitis models - An experimental study using intravital microscopy and a new histological scoring system, Digest. Dis. Sci. 46 (2001) 2336-2343.

[27] P. Chomczynski, N. Sacchi, Single step method of RNA isolation by acid guanidinium thiocyanate-phenol-chloroform extraction, Anal. Biochem. 162 (1987) 156-159.

[28] G.K. Smyth, Limma: linear models for microarray data, in: R. Gentleman, V. Carey, S. Dudoit, R. Irizarry, W. Huber (Eds.), Bioinformatics and Computational Biology Solutions using R and Bioconductor, Springer, New York, 2005, pp. 397-420.

[29] W.S. Selby, G. Janossy, D.Y. Mason, D.P. Jewell, Expression of HLA-DR antigens by colonic epithelium in inflammatory bowel disease, Clin. Exp. Immunol. 53 (1983) 614-618.

[30] M. Reinshagen, C. Loeliger, P. Kuehnl, U. Weiss, B.J. Manfras, G. Adler, B.O. Boehm, HLA Class II gene frequencies in Crohn's disease: a population based analysis in Germany, Gut 38 (1996) 538-542.

[31] E.A. Trachtenberg, H. Yang, E. Hayes, M. Vinson, C. Lin, S.R. Targan, D. Tyan, H. Erlich, J.I. Rotter, HLA Class II haplotype associations with inflammatory bowel disease in Jewish (Ashkenazi) and non-Jewish caucasian populations, Hum. Immunol. 61 (2000) 326-333.

[32] L.M. Yap, T. Ahmad, D.P. Jewell, The contribution of HLA genes to IBD susceptibility and phenotype, Best. Pract. Res. Clin. Gastroenterol. 18 (2004) 577-596.

[33] D. Hwang, Modulation of the expression of cyclooxygenase- 2 by fatty acids mediated through Toll-like receptor 4-derived signaling pathways, FASEB J. 15 (2001) 2556-2564.

[34] Y.E.M. Dommels, M.M.G. Haring, N.G.M. Keestra, G.M. Alink, P.J. van Bladeren, B. van Ommen, The role of cyclooxygenase in $n-6$ and $n-3$ polyunsaturated fatty acid mediated effects on cell proliferation, PGE2 synthesis and cytoxicity in human colorectal carcinoma cell lines, Carcinogenesis 24 (2003) 385-392.

[35] J.Y. Lee, A. Plakidas, H.W. Lee, A. Heikkinen, P. Chanmugam, G. Bray, D.H. Hwang, Differential modulation of Toll-like receptors by fatty acids: preferential inhibition by $n-3$ ployunsaturated fatty acids, J. Lipid Res. 44 (2003) 479-486.
[36] T.M. Stulnig, Immunomodulation by polyunsaturated fatty acids: mechanisms and effects, Int. Arch. Allergy Immunol. 132 (2003) 310-321.

[37] R.P.J. Oude Elferink, C.C. Paulusma, Function and pathophysiological importance of ABCB4 (MDR3 P-glycoprotein), Pflugers Arch. Eur. J. Physiol. 453 (2007) 601-610.

[38] T. Langmann, C. Moehle, R. Mauerer, M. Scharl, G. Liebisch, A. Zahn, W. Stremmel, G. Schmitz, Loss of detoxification in inflammatory bowel disease: dysregulation of pregnane $\mathrm{X}$ receptor target genes, Gastroenterology 127 (2004) 26-40.

[39] I.C. Lawrance, C. Fiocchi, S. Chakravarti, Ulcerative colitis and Crohn's disease: distinctive gene expression profiles and novel susceptibility candidate genes, Hum. Mol. Genet. 10 (2001) 445-456.

[40] Y.E.M. Dommels, C. Butts, S.T. Zhu, M. Davy, S. Martell, D. Hedderly, M.P.G. Barnett, W.C. McNabb, N.C. Roy, Characterization of intestinal inflammation and identification of related gene expression changes in mdr1a $\mathrm{a}^{-1-}$ mice, Gene Nutr., 2 (2007) in press.

[41] R.J. Passey, K. Xu, D.A. Hume, C.L. Geczy, S100A8: emerging functions and regulation, J. Leukoc. Biol. 66 (1999) 549556.

[42] C. Kerkhoff, C. Sorg, N.N. Tandon, W. Nacken, Interaction of S100A8/S100A9-arachidonic acid complexes with the scavenger receptor CD36 may facilitate fatty acid uptake by endothelial cells, Biochemistry 40 (2001) 241-248.

[43] J. Bassaganya-Riera, R. Hontecillas, CLA and $n-3$ PUFA differentially modulate clinical acitivity and colonic PPAR-responsive gene expression in a pig model of experimental IBD, Clin. Nutr. 25 (2006) 454-465.

[44] A. Ido, M. Numata, M. Kodama, H. Tsubouchi, Mucosal repair and growth factors: recombinant human hepatocyte growth factor as an innovative therapy for inflammatory bowel disease, J. Gastroenterol. 10 (2005) 925-931.

[45] P.R. Devchand, H. Keller, J.M. Peters, M. Vazquez, F.J. Gonzalez, W. Wahli, The PPARalpha-leukotriene B4 pathway to inflammation control, Nature 384 (1996) 39-43.

[46] P.G. Reeves, F.H. Nielsen, G.C. Fahey Jr., AIN-93 purified diets for laboratory rodents: final report of the American Institute of Nutrition ad hoc writing committee on the reformulation of the AIN-76A rodent diet, J. Nutr. 123 (1993) 1939-1951. 